\title{
New Perspectives in Combating Child Trafficking and the Shift to an Effective Child Protection in Nigeria
}

\author{
Alexis Foua1, Wilson Diriwari² \\ ${ }^{1}$ Lecturer in Law at Arden University, London, United Kingdom \\ ${ }^{2}$ Solicitor in England and Wales, London, United Kingdom \\ Email: Afoua@arden.ac.uk,wilson@wsolicitors.co.uk
}

How to cite this paper: Foua, A., \& Diriwari, W. (2019). New Perspectives in Combating Child Trafficking and the Shift to an Effective Child Protection in Nigeria. Beijing Law Review, 10, 1239-1261. https://doi.org/10.4236/blr.2019.105067

Received: November 9, 2019

Accepted: December 7, 2019

Published: December 10, 2019

Copyright $\odot 2019$ by author(s) and Scientific Research Publishing Inc. This work is licensed under the Creative Commons Attribution International License (CC BY 4.0).

http://creativecommons.org/licenses/by/4.0/ Open Access

\begin{abstract}
The Article examines the challenging issues of child trafficking and the new perspective in combating the phenomenon in Nigeria. It shows the multiplicity and the complex nature of the problem which has social, cultural and political underpinnings. The lack of genuine political will and focus on addressing the factors per se contributes to the perpetuation of the phenomenon. The need for the identification and eradication of child trafficking has become a matter of urgency, hence a particular attention from authorities and all stakeholders is deemed an imperative. The article focuses on the legal and political approach adopted by Nigerian law and policy makers in recent years. The article evaluates the achievements made through various actions undertaken to eliminate the phenomenon. It concludes that there are shortcomings although the new approaches adopted as the Nigerian authorities have yet to deliver in the area of child trafficking and the protection of children's rights.
\end{abstract}

\section{Keywords}

Child Trafficking, Culture, Traditions, Child Protection, Legal Instruments

\section{Introduction}

In providing a clear definition to the concept of child trafficking, the ILO (2010) notes that "A child has been trafficked if he or she has been moved within a country, or across borders, whether by force or not, with the purpose of exploiting the child" reports about child trafficking. In the global context, it is often reported that the phenomenon is in decline (US Department of States, 2015). However, all actors involved in combating the phenomenon must make more 
efforts at national levels. Paradoxically, most developing countries, especially those in the sub-Saharan region, appear to fail to adopt new strategies in accordance with the requirements imposed by globalisation.

According to Matsumoto (2007: p. 16) culture is the set of attitudes, values, beliefs, and behaviors shared by a group of people, but different for each individual, communicated from one generation to the next. It is observed that culture and tradition account significantly for the complex nature of the phenomenon of child trafficking in Nigeria. In such state of quagmire, it was obvious that ambitious projects such as the Millennium Development Goals (MDGs) could not be completely achieved globally by 2015 (United Nations, 2015). Equally, there is no guarantee that future projects despite their sublime nature may be completed. Indeed as long as the real issues remain unaddressed, it is unlikely that permanent solutions are found to the issue of child trafficking and child protection in Nigeria.

An attempt to perceive Child Trafficking from the human rights perspective shows an endeavour to place greater emphasis on the critical nature of the issue not only in Nigerian society but also in the globe. Hence, the fight against child trafficking in Nigeria requires a paradigm shift in approach which should rest upon a thorough analysis of the contributing factors. The new approaches constitute the way forward for Nigeria in regard to the lingering issue of child trafficking and child protection. Under the provision of article 19 of the United Nations on the Rights of the Child, the protection of children must be in and out of the home. ${ }^{1}$ Child protection therefore is the protection of children from violence, exploitation, abuse and neglect. Undoubtedly, the issue of child protection which embodies the child trafficking narrative will also be addressed once for all.

\section{New Approach to Addressing the Contributing Factors}

\subsection{The Issue of Child Fostering in Nigeria}

Child fostering has been presented as one of the major contributing factors to the thriving of child trafficking in Nigeria (Aderanti, 2002). Indeed child fostering in West Africa per se is a practice observed in conformity with the cultural and traditional perception of solidarity and community support. In Nigerian communities as well as in most Sub-Saharan African countries "family" is conceptualised as more than the biological mother, father and children. It is convenient for parents to surrender the upbringing of let their children to other relatives who share responsibility for their care and to whom they are obligated throughout life (Oni, 1995). To some extent, the support of the child is provided by the community when necessary. Hence, the practice of child fostering has existed in West Africa for centuries.

Child fostering as an alternative to the biological family environment and the condition has functioned in harmony and decency and help West African com-

${ }^{1}$ United Nations Convention on the Rights of the Child (1989), Article 19. 
munities to remain stable despites problem-related to the orphanage, or disintegration of the child biological family for any reason. However, the new context of modern Nigeria the increasing economic and financial needs of the population which is often characterised by greed, have distorted the then moral and humanist rational behind the practice. In such context, the lack of legal framework to organise the practice has worsened the situation thereby leading to all type of abuses towards children. As emphasised hereinbefore, the practice has always well functioned even without the Nigerian legal system which was later set by the colonial administration, but the debate arose when in modern day $\mathrm{Ni}$ geria various issues have led to the abuse of the practice once regarded as the characteristic of solidarity and cement to social stability. Indeed cupidity, greed and growing disregard for basic human rights have set the ground for abuses and the criminal activity of child trafficking. Hence the current state of affairs appeals to the authorities, law and policy makers as well as the wide community of scholars. As child fostering is a breading ground for child trafficking efforts are made to regulate child fostering in Nigeria. Regulating adoption in Nigeria is regarded as a significant move in the area of child welfare. The regime for adoption has been clarified under the provision Section 125(1) of the Child Rights Act 2003. ${ }^{2}$ Even though adoption has been regulated in Nigeria there are still shortcomings in the implementation.

\subsection{The Implementation of Legislations}

The issue of implementation and enforcement are recurring problems in Nigerian legal environment. Although the Child Rights Act has sufficiently elaborated on the requirements for an effective child rights protection in Nigeria, the fact that its full implantation and to some extent the enforcement of some provisions remain a far-fetched, the prospect of succeeding in the creation of a workable legal framework for child fostering is meagre. The crucial nature of the question led Chukwu (2012) to observe that the absence of such approved adoption services in Nigeria has created a yawning gap which private maternities and orphanages exploit by indulging in the illicit acts of child trafficking and facilitating unauthorized adoption. The lack of implementation or the difficulties of an effective enforcement raise not only the question of efficacy of the law but also the creation of condition for effective implementation and enforcement. From the above observation, it could be asserted that the lack of implementation

${ }^{2}$ See Child right Act 2003 Section 125(1) Every State Government shall, for the purpose of adoption, establish and maintain within the State and, in the case of the Federal Government, within the Federal Capital Territory, Abuja a service designed to meet the needs of: 1) a child who has been or may be adopted; 2) parents and guardians of the child specified in paragraph 1) of this subsection; and 3) persons who have adopted or who may adopt a child, and for this purpose, every Government shall provide me requisite facilities or ensure that me facilities are provided by approved adoption services as may be prescribed by the appropriate authority. (2) The facilities to be provided as part of the services maintained under subsection (1) of this section include: 1) temporary board and lodging, where needed by a child and, in exceptional circumstances the mother of a child; 2) arrangements for assessing a child and prospective adopters and placing of the child for adoption; and 3) counselling for persons with problems relating to adoption. 
or enforcement is not always due to cultural and traditional factors but the inaction of the authorities. It must be admitted that in addition to the new approach to be adopted in regard to the contributing factors to child trafficking, there must also be a new approach to children's participation in Nigerian society.

\section{New Approach to Children's Participation in Society}

\subsection{The Legal Approach}

Children's involvement in work is a complex issue. In certain contexts ${ }^{3}$ children's participation to work is not regarded as a wrong approach. Therefore it cannot be seen as a despicable practice. It does not have negative impacts on the child's condition or his/her future life. Instead, it contributes to the child's development and serves as training for future experiences or adult life. For instance, Section 49 (1) of the Nigeria Labour Act 1990 requires the parents or guardians of the young person aged between twelve and sixteen years to testify with the consent of that young person in the execution of a written contract of apprenticeship. ${ }^{4}$ In this case, the young person enters into an employment contract for the purpose of training.

More significantly, for the purpose the child's welfare and safety, section 18 (1) of the Act provides that "Every worker shall be entitled after twelve months continuous service to a holiday with full pay. The worker is entitled to 1) at least six working days; or 2) when the person under sixteen (including apprentices), at least twelve working days." It emerges from this provision that the welfare of the child is taken into consideration in allocation holiday durations. Furthermore, the Labour Act provides an answer in the case where the child has no known parent or guardian to act on his /her behalf the state acts as a legal representative for the child. ${ }^{5}$ The debate on children's participation in work is significant in that it intends to shed light on the flawed interpretation of the act. Indeed children's participation to work as perceived by Nigerian law, as well as the laws of most countries, is deemed to be conducted in observance of the children's rights. Thus, in a condition where the child works as an apprentice as long as the employer abides by the relevant regulation, the child's welfare and safety are guaranteed. The likelihood of his/her basic rights being violated is meagre. However, there are situations where the child's welfare is threatened or his/her future is jeopardised.

\subsection{The Historical and Traditional Perspectives}

Historically, children's participation in work has been determinant to the devel-

\footnotetext{
${ }^{3}$ Activities such as children helping their parent to rear the cattle or some types of farms works to produce foods for the family's own consumption are not often regarded as child labour.

${ }^{4}$ See Labour Act, Chapter 198, Law of the Federal Republic of Nigeria. Available at http://www.nigeria-law.org/LabourAct.htm, accessed 19 August 2019.

${ }^{5}$ Labour Act 1990 Section 49(2) Where a young person above the age of twelve years and under the age of sixteen years is without known parents or a guardian, an authorized labour officer may authorize the apprenticeship of that person and appoint some fit and proper person to execute the written contract of apprenticeship and act generally as guardian of that young person.
} 
opment of most of the current industrialised nations. For instance, children's participation to work has been one of the pillars of the industrial revolution in England (Williamson, 1991; Thompson, 1966: p. 307). Equally children's involvement in work has been crucial to the subsistence of traditional communities around the globe. Children in traditional African societies were central to the life of the community. Traditional African communities were essentially reliant on farming and cattle rearing. Hence, according to their age, children had to play a specific role in the process (Ekpere, Oyedipe, \& Adegboye, 1978). Comparatively, children's participation in the industrial revolution and children's participation to farming and cattle rearing in traditional African communities were both conducted with the same aim: massive gain. This aim for massive gain could be translated into increased productivity, food security, and development. From a theoretical approach, the whole idea could be encapsulated in the functionalist perspectives. Indeed on the assumption that institutions are put in place for the better running of the community and society. The evidence functionalist perspectives in the institutionalisation of children's participation are the sustainability of the community (Pope, 1975). However, children's participation in work took the form of systematic and despicable exploitation.

On the basis of traditional perceptions or customary settings, the children's participation in work is not seen as something wrong whatsoever. As long as the child can work, no question is raised about the detrimental aspect of such work on the child's welfare or future. The community will rather focus on the benefits of the child participation to the good functioning of the community, as it is viewed by the theory of functionalist perspectives. ${ }^{6}$ The experience of law implementation and enforcement for the betterment of children's conditions in industrialised nations has been enjoyed for decades, and it endures.

\subsection{The Human Rights Approach}

Because children's participation in work was conducted in total denial of their basic human rights, voices were raised to advocate for a paradigm shift in approach to the child's welfare (Roose, \& Bourne-De Bie, 2007). Eventually, the move was followed by other western countries (Marshall, 1992). The paradigm shift in approach is indeed materialised by the enactment of laws that are effectively implemented and enforced to eradicate the phenomenon. Moreover, the exploitation of children is made to be perceived as immoral by society. Although the conditions of children in regard to exploitation have progressively improved over several decades, there are still cases of exploitations. A Report published by the United States Department of Labor in 2015 evidenced the practice of child labour in its worst forms in Nigeria despite the adoption of a legal framework to

${ }^{6}$ The functionalist theory postulates that institutions come about and persist because they play a function in society, promoting stability and integration. It presents social institutions as collective means to meet individual and social needs. In applying this to child trafficking, it could be asserted that those who engage in the activity perceive the participation of children in various works after being trafficked is important for the sustainability of their communities. 
combat the problem. ${ }^{7}$

Overall, the conditions of children are much better in western societies today compare to the era of industrial revolution and epoch before that revolution. It is evident that developing countries have followed the path of the law and policy response in regard to the issue of children's participation to work and their systematic exploitation, but there are shortcomings in the implementation and enforcement aspects. Indeed apart from the contextual realities that often render enforcement almost impossible the enforcement, Bradford and Ben-Shahar (2012) observe that sanctions are costly to impose, difficult to coordinate, and often international laws/re ineffective at accomplishing their goals (Bradford and Ben-Shahar, 2012). Therefore the discourse about children's participation and the need for new approach to the issue in society appeal more to developing countries where communities upholding traditional values still exist.

\section{New Approach to the Elements of Culture and Tradition}

The lack of implementation or enforcement of international legal instruments has often been blamed on the adverse nature of local cultures (Zwari, 2012). As indicated hereinbefore, traditional views often conflict with modern imperatives (O'Brien, 2006). Hence in a wider ambit, the complex cultural context of Nigeria does not often permit the straightforward implementation or enforcement of international legal instruments especially those related to human rights.

Oyowe (2014) writes that the belief that human rights are culturally relative has been reinforced by recent attempts to develop more plausible conceptions of human rights whose philosophical foundations are closely aligned with culture-specific ideas about human nature and/or dignity. It derives from this analysis that approaches to human rights vary according to the cultural context. Nigeria is a country where over 300 tribes live. ${ }^{8}$ From the north to the south, from the east to the west there are various communities with various religions, custom and traditions. In such context, the cultural relativist discourse becomes significant.

The perception of human rights in general and child rights, in particular, will not be the same in the north where Islamic values will prevail in dealing with the child's upbringing. For instance, the Almajiri system established in the north has been possible because the authorities of independent Nigeria allowed the legal pluralist context that permits the sharia system in the Islamised northern Nigeria. Although the word almajiri originated from Arabic, it has been adapted in Hausa society in northern Nigeria. Thus, Magashi (2015) writes that in a Nigerian context, it could mean a boarding student of Islamic studies; a student learning the science of the Qur'an, believed to be the revealed book of Almighty God, while committing the text to memory; a small child sent to an itinerant ${ }^{7}$ United States Department of Labor, 2015 Findings on the Worst Forms of Child Labor'. Available at https://www.dol.gov/agencies/ilab/resources/reports/child-labor/nigeria, accessed 19 October 2019.

${ }^{8}$ See Answer Africa, "Nigerian Tribes: List of Major Tribes in Nigeria.” Available at http://answersafrica.com/nigerian-tribes.html, accessed 1 September 2019. 
teacher to learn not just the Islamic religion, but also how to pursue a means of livelihood for himself, his teacher, and his family, or even, to many uninformed Nigerians, a beggar.

As indicated, cultural relativism has been the rationale behind the maintaining of a legal pluralistic environment in Nigeria. The Colonial Administration has taken the approach, and it has been maintained by the Nigerian authorities after independence was granted to the country by Great Britain in 1960. It is evident that Nigerian authorities have allowed this system to carry to avoid recurring conflicts based on cultural perceptions in a country where communities remained deeply attached to their religion, customs and tradition. Hence system such as Almajiri and other cultural violence ${ }^{9}$ have prevailed alongside the modern systems fostered and promoted by the Federal and local governments. This approach is evidenced in the Federal government's domestication procedure of international legal instruments. The Nigerian Constitution places the issues of child rights are under States' responsibility and jurisdiction. As such, States are expected to formally adopt and adapt the Child Rights Act for domestication as State laws. Hence The Act becomes fully operational only when a State adopts it. As a result, only 16 States have promulgated the Act into Law. ${ }^{10}$ Obviously, most States in Northern Nigeria have not promulgated the Act. Hence the Federal and State Ministry of Women Affairs was urged by UNICEF, to make sure that all States adopt the Child Rights Act. ${ }^{11}$

In other part of Nigeria, traditional beliefs have constituted serious challenges to the implementation of laws hence child rights violations were systematic and frequent. For instance, Liepe observes that 'beliefs in the existence and powers of witches have a long and diverse history and span a large range of cultures and traditions (Liepe, 2016). Indeed the dominance of traditional and cultural beliefs in most Nigerian communities has been somehow tolerated on the same ground that every community has the rights to express their beliefs and maintain their traditional values and customary practices. On the issue of witchcraft, children are often the most vulnerable when it comes to accusations. Hence Secker (2013) writes that:

"Witchcraft stigmatization is increasingly identified as a growing human rights concern. The stigmatization of children as witches and resultant child rights abuse is particularly prevalent in Nigeria, and has been recognized as a major barrier to the effective implementation of child rights in this state. Witch-

${ }^{9}$ In Nigeria, there are many cultural practices that are acts of violence on the child. These include female genital mutilation (otherwise called female circumcision), tribal marking and scaring, rites of passage (for instance from childhood to adulthood), initiations, marriage ceremonies, etc. In different parts of Africa, these cultural practices are carried out on children with or without their consent. Physical and psychological damage often results and some children may even die from such practices.

${ }^{10}$ The States ae as follows: Abia, Anambra, Bayelsa, Eboniyi, Edo, Ekiti, Imo, Jigawa, Kwara, Lagos, Nassarawa, Ogun, Ondo, Plateau, Rivers and Taraba.

${ }^{11}$ UNICEF Nigeria, Action'.Avaialble at

http://www.unicef.org/nigeria/protection_2169.html, accessed 26 July 2019. 
craft-related abuse entails significant violations of a range of children's rights, and is yet to receive adequate or effective policy responses from government. Whilst Civil Society Organizations have attempted to address this issue, significant practical and conceptual challenges to their work remain."

Secker's observation is significant in that it underscores one of the key factors of the rejection of children in Nigeria. A child accused of witchcraft is usually killed or abandoned by his /her biological parents and other members of the extended family (Withnall, 2016). The abandoned children are often exposed to all sorts of abuses by strangers. Some of them fall prey to traffickers. In such cases of extreme child rights violations should the cultural relativist argument prevail in all area of life in Nigerian society, there would have been serious damages to social stability and development. It is to be acknowledged that the central issue in the debate on cultural relativism is the protection of human rights as a value. On that issue, Donnelly (1984) writes that:

" $A$ cultural relativist account of human rights, however, seems to be guilty of logical contradiction. If human rights are based in human nature, on the simple fact that one is a human being, and if human nature is universal, then how can human rights be relative in any fundamental way?"

There cannot be a valid answer to that question in that child rights in Nigeria equates to child rights in any other country of the world. There may be a problem of culture but the paradigm shift in approach to human rights in general and child rights in particular need to be outside the discourse on cultural relativism. The discourse shall not hamper the establishment the manifestation of law and order. Hence the Nigerian authorities have the duty to address the adverse effects of culture in assessing the effectiveness of human trafficking laws in general. The pluralistic environment of the Nigerian legal system appears to be a plausible answer to the question of relativism.

It should be recalled that legal pluralism is regarded as a trade-off between the legal system established by the colonial administration and local traditional and customary settings in Africa.

\section{The Need for an Effective Cooperation among Stakeholders}

It worth recalling that child trafficking is a despicable practice as it dehumanised the child. Hence it is important to created condition of an effective cooperation among stakeholders in order to combat the phenomenon worldwide. This cooperation is not only imperative among ECOWAS States but also between these States and other countries involved in child trafficking from Nigeria.

\subsection{The Cooperation among ECOWAS States}

Effective cooperation within the Economic Community of West African States' (ECOWAS) is vital in addressing child trafficking and its underlying problems. ECOWAS established as a sub-regional organisation chose for its effective op- 
eration to apply the principle of free movement of a person between states members. However, the adequate accompanying measures to make the principle viable have not yet been devised. Effective Cooperation in the context of regional integration stands as the central pillar of the real success. The ECOWASProto$\mathrm{col}^{12}$ is a significant instrument in the organisation's desire to succeed in its regional economic integration perspective. ${ }^{13}$ The Protocol Recalling, the sub-paragraph (d) of paragraph 2 of Article 2 of the Treaty of ECOWAS, calls on the Member States to ensure by stages the abolition of the obstacles to free movement of persons. However, the principle of free movement does not provide that people can travel without a passport or other form of identification, a report published by ECOWAS estimated that about $70 \%$ of border residents cross the border frequently without any form of documentation/identification. ${ }^{14}$ Hence the ECOWAS free movement programme involving visa abolition for travel by citizens within the Community is seriously exploited by all sorts of cross-border criminals including human traffickers.

Millions of people including children to move between States without being properly identified by border agency staffs. As a result, human trafficking in general and child trafficking, in particular, thrive across Nigerian borders. Although traffickers send victims to countries outside the ECOEWAS zone, it should be understood that the majority of the trafficked persons including children are disseminated across Members States of the organisation for various types of exploitations. Therefore, the organisation took various actions to address the issue. The major steps taken so far by ECOWAS are the initiation of two projects.

The projects, ECOWAS I\& II, designated as "Eliminating the Worst Forms of Child Labour in West Africa and Strengthening Sub-Regional Cooperation through ECOWAS” were initiated in line with ILO/IPEC intervention programmes. The programmes essentially motivated by the high incidence of the worst forms of child labour in some member states, especially in Benin and Nigeria. The two projects contextualised in the hazardous labour frame of the ILO-IPEC initiative had the vision of not only addressing the problems of children at risk but also ensuring that some of the root causes of the issues such as abject poverty, social challenges and ignorance are dealt with in a practical and sustainable manner. It acknowledged that the Nigerian government's full involvement in the project accounted in large for its success in that the Ministries of Labour and Education, as well as NAPTIP and the police, have played their

${ }^{12}$ The ECOWAS Protocol on Free Movement of Persons, Residence, and Establishment adopted on 29 May 1979.

${ }^{13}$ See ECOWAS protocol. Document available at

http://www.cfr.org/world/economic-community-west-african-states-ecowas-protocol-free-moveme nt-persons-residence-establishment/p28124, accessed 26 August 2019.

${ }^{14}$ See Ecowas Protocol A/P.1/5/79 Relating to Free Movement of Persons, Residence and Establishment. Available at

https://documentation.ecowas.int/download/en/legal_documents/protocols/PROTOCOL\%20RELA TING\%20TO\%20\%20FREE\%20MOVEMENT\%20OF\%20PERSONS.pdf, accessed 26 August 2019. 
role in facilitating the process and enforcing the law. ${ }^{15}$ However, the projects are deemed a success in the ECOWAS there are still significant progress to be made

Among other problems created by the ineffective management of the principle of free movement of persons, child trafficking should be addressed with a particular attention. Indeed legislation does not constitute the problem in the discourse about child trafficking in ECOWAS area because most of the member states have enacted the necessary laws for that purpose. Instead, there is a need to adopt a new approach to addressing the issue not only at the law and policy structure of the organisation but also an effective response from states members towards the issue. This approach implies that Ecowas officials must take into account all the strategies and mechanisms employed by criminals. Some countries in addition to the measure adopted by the organisation, have signed bilateral treaties to address the issue in accordance with their contextual realities. Child labour in West Africa is one of the thriving practices that have favoured the increase of child trafficking in the region. It is understood that children are trafficked for various activities in the countries of destination. They are sent to countries where there is high demand for labourers. Children are used as child labourers on cocoa farms, quarries, construction and domestic works as well as others hazardous works. However, such practice is despicable it remain a fact in West Africa.

In the light of the seriousness of the problem, in addition to existing measure at the community level, some member states have signed bilateral treaties to address the issue of worst forms of child labour. ${ }^{16}$ Likewise, at the state level, some members have increased their legislative activities to overcome the phenomenon locally. In terms of legislation and actions undertaken at both community and national levels, it could be asserted that efforts have been real. However, there seem to be less satisfactory results on the ground. Lawrence (2010) in his assessment of the Ghanaian law about trafficking and labour issues observed that 'the Ghanaian law is of limited effectiveness: Rather than engaging with autochthonous causes, including complex social practices with historically rich traditions (like child fosterage, rearing, and labor), it enjoined a narrow, economic model for the proliferation of trafficking. Lawrence's observation is pertinent in that is describes a stereotype in the whole ECOWAS area. ${ }^{17}$ All Member States appear to adopt the same attitude towards the issue. They rarely address the root cause referred to hereinbefore.

\subsection{The Cooperation with Other Countries}

The new approach to cooperation with countries of destination for victims of ${ }^{15}$ See ILO, "Good practices and lessons learned on the elimination of child labour in Nigeria: ECOWAS projects' experiences.” Available at http://www.ilo.org/ipec/Informationresources/WCMS_IPEC_PUB_26975/lang--en/index.htm, accessed 25 August 2019.

${ }^{16} \mathrm{~A}$ bilateral agreement between Mali and Cote d'Ivoire in September 2000 to combat the transborder phenomenon of child trafficking.

${ }^{17}$ ibid. 
trafficking is to be taken for more efficiency in the combat against child trafficking. Although efforts are evident within Nigeria and the ECOWAS area, actions need to be taken beyond the borders of Nigeria and ECOWAS. The approach is to be adopted in cooperation with countries in Central Africa, North Africa, Middle East and Europe. In a report from the U.S. Department of State, it is noted that:

"Nigerian women and children are recruited and transported to destinations in North Africa, the Middle East, and Central Asia, where they are held captive in the sex trade or in forced labor. Nigerian gangs subject large numbers of $\mathrm{Ni}$ gerian women to forced prostitution in the Czech Republic and Italy. Moreover, West African women transit Nigeria to destinations in Europe and the Middle East, where they are subsequently subjected to forced prostitution. Children from West African countries are subjected to forced labor in Nigeria, including in Nigeria's granite mines. Nigeria is a transit point for West African children subjected to forced labor in Cameroon and Gabon." 18

Obviously, Nigeria is a significant platform for human trafficking in general and child trafficking in particular. There are several countries of destination in relation to the trafficking issue in Nigeria. An effective cooperation implies that Nigeria's foreign policy should place greater emphasis on bilateral cooperation with each one of the countries identified as the most preferred destinations for Trafficked persons from Nigeria. Whereas most countries of destination have the infrastructures and resources to combat trafficking within their borders $\mathrm{Ni}$ geria is often incapable to face some challenges related to the issue. To a great extent child trafficking is detrimental to Nigeria socioeconomic stability and development goals. Although human trafficking is an underground industry, it does not impact negatively the socio-economic development of the countries of destination. They rather benefit from it in that it provides cheap labour. However, the main challenge facing these countries of destination remains the usual issues of human rights violations. In the absence of an effective cooperation sustained by an adequate foreign policy from Nigeria, it becomes more challenging for the authorities to engage their counterparts in the fight against child trafficking.

In its bilateral cooperation with each one of the countries identified as a preferred destination for person trafficked from Nigeria. They should be focused on bilateral law enforcement cooperation including training programmes for law enforcement officers to tackle human trafficking and deal with the victims of trafficking where necessary, mutual assistance and extradition Targeting people smugglers and traffickers in a well-organised intelligence sharing data system. A $\mathrm{BBC}$ report unveiled that girls are given forged documents and passports from Nigeria to fly into places like Gatwick. These documents are often obtained with the complicity of people working in the government (BBC Magazine, 2016). In such circumstances, a close and effective cooperation between Nigerian immi-

${ }^{18}$ See U.S. Department of State, 2015 Trafficking in Person Report: Nigeria. Available at http://www.state.gov/j/tip/rls/tiprpt/countries/2015/243505.htm, accessed 27 August 2019. 
gration officials and the UK Border Agency is necessary to prevent fraudsters from worsening the situation of human trafficking and child trafficking.

\section{The Shift to an Effective Child Protection}

Child protection in Nigeria will require the setting of a workable protection system and the constant raising of public awareness to child rights and child protection questions in Nigeria.

\subsection{Setting a Workable Child Protection System in Nigeria}

Approaches to be taken in the child protection discourse are the needs-based approach and the rights-based approach. The basic needs of the child are to be seen in five categories. The child needs someone to believe, someone who will be regarded as role model; every child needs to believe in something: values; every child needs to belong somewhere: a family and community; every child needs something to becoming: aspiration to significance and pursuit of inner potential; every child need the affirmation of his freedom and responsibility: a sense of dignity and self-worth. There are four structures of protection for the child is the family, the community, the state and international community. In this circle, the family constitutes the primary caregiver whereas the community, the state and the international community remain the secondary caregivers. The Community, the State and International Communities exist to strengthen the family institution and not to take over its inevitable roles. Indeed it should be acknowledged that we work with and for children because it is their rights to be protected. Hence it could not be said that we are doing them a favour. Protecting children is a matter of necessity that we protect them, and that must be our attitude.

The idea of child protection has been widely spread among law and policy makers at both national and international levels. Meanwhile, child protection is still regarded as a thorn in most governments' flesh in developing countries. The paradigm shift in perception about the issue has yet to be made in order to bring about the effective child protection. It appears that despites the ratification of most international instruments about the welfare of the child and its adherence to human rights values; Nigeria has not seen the change expected in the area of child protection in general. According to UNICEF, society condones most of the violence aginst children tacitly or explicitly. ${ }^{19}$ Indeed several practices existing in communities endure because of the attitude of the community towards them. ${ }^{20}$

${ }^{19}$ See UNICEF, “Progress for Children: A Reort Card on Child Protection”. Available at http://www.unicef.org/protection/files/Progress_for_Children-No.8_EN_081309(1).pdf, accessed 29 July 2019.

${ }^{20}$ The practices are child marriage, female genital mutilation/cutting, corporal punishment and domestic violence. Effective child protection depends on to a large extent on changing the mindsets of families and communities so that attitudes, beliefs and practices that harm children will no longer be tolerated. Positive social consensus reinforces the most effective child protection. Attempts to impose change from outside often lead to resistance. Initiatives to improve child protection are more effective when they are based on partnerships and coalitions, and when open discussion of the issues can take place. Change that is effective and sustained will be rooted in shared social norms and effective, accessible systems. 
The community usually tolerates it or simply fail to report it to the authorities because it profits them.

UNICEF's observations about the issue of mindsets are so pertinent that its subsequent report on the determining factors for non-registration of children at birth are essentially based on cultural or religious views. Indeed mindsets usually derive from cultural perception, traditional settings or long-standing practices within communities (Oyserman, 2011). It is noted that the unregistered children are from a different ethnic group, nationalities, religion, children born out or wedlock or children whose parent fled wars from localities where there is low birth registration. ${ }^{21}$

Because mindsets are designated as the main factors for the plight of children in most Nigerian communities, UNICEF underscores that effective child protection depends on to a large extent on changing mindsets. Indeed this equates to the need for a paradigm shift in perception referred to hereinbefore. The change of mindsets does not concern families and communities alone. It also concerns government authorities and law enforcements agencies. Without being a welfare state, Nigeria as a nation aspiring to become an important member of the international community should promote values that perpetuate the welfare of the child in general.

The change of mindsets alluded to by the UNICEF can happen if Nigerian authorities create the necessary conditions for its materialisation. While all traditional perceptions cannot be viewed as a hindrance to the manifestation of effective child protection, those considered to have such impact should become properties on the government's agenda for addressing social issues that hamper the development of Nigeria. The change to be instigated by Nigerian authorities will require their real political will, their capacity of persuasion within traditional communities, and their ability to materialise the implementation and enforcement of relevant laws and policies.

\subsection{The Importance of Child Registration at Birth and Formal Education}

It must be admitted that the child must be recognised in the administrative apparatus before standing the chance of accessing formal schooling. It becomes evident that a child born without being formally registered at birth is highly likely to be lost in the population hence unknown to the authorities. Among other issues underpinning the discourse on child trafficking, the non-identification of the child remains crucial. A child without a birth certificate is less likely to be sent to school or even if he or she is, there is a high probability that she or he is refused admission for the lack of official documents. As a result, such child is exposed to phenomena like child trafficking and child labour.

The Nigerian Constitution does not have a specific provision about registra-

${ }^{21}$ See UNICEF, Birth Registration in Nigeria: Impact Evaluation Report on Birth Registration in Nigeria from 2012-2016. Available at

https://www.unicef.org/nigeria/reports/birth-registration-nigeria, accessed 16 August 2019. 
tion at birth. However, after almost over two decades of independence, the authorities resolved to address the issue at least from a legislative perspective. It is acknowledged that the fist conscious effort to have a universal system of registration of births and deaths was made in 1988 when the government promulgated the births and Deaths Compulsory Registry Decree 39 of 1979. Indeed the decree was aimed at establishing a uniform national and State-level registration. The conditions for birth registration were made less stringent on some occasion to allow parents to register their children. ${ }^{22}$ Moreover, the right for every child to be registered at birth, to acquire a name and nationality, and the responsibilities of the States in this area are provided by other international legal instruments that Nigeria has ratified. The relevant provisions are Article 15 of the Universal Declaration of Human Rights $1948^{23}$, article 24 of International Covenant on Civil and Political Rights ${ }^{24}$, Article 7 of the UN CRC $1989^{25}$, and Article 6 of the African Charter on the Rights and Welfare of the Child 1990. ${ }^{26}$

In its report on a country study about Nigeria, UNICEF has observed that there has been remarkable efforts to reform the sector of Education in the country. The report indicates that however, some positive gains have been recorded in some aspects as a result of these interventions and reform initiatives more efforts have to be made. ${ }^{27}$ These facts come as a concern for authorities efforts to improve the sector hence eliminate all the surrounding social predicament of a child due to the lack of schooling. Children could be best protected if they attend school on a regular basis and therefore they accounted for by the system. Education will develop the child's skills to face social issues during the process of his/her growth and adult life.

Investing in education and training can play a paramount role in helping to break the cycle of poverty and should be emphasised in all development plans and programs. Research has shown that educating girls, especially through sec-

\footnotetext{
${ }^{22}$ Federal Government's Decree No. 69 of 1992 on vital registration provided that registration shall be free of charge, within a period of 60 days from the date of birth, the Child Rights Act 2003 provides in its Section 5 that: 'Every child has the right to a name, and the birth of every child shall be registered.

${ }^{23}$ The Universal Declaration of Human rights Article (15) 1, everyone has the right to a nationality; 2 , No one shall be arbitrarily deprived of his nationality nor denied the right to change his nationality.

${ }^{24}$ See International Covenant on Civil and Political Rights, Article (24) 1) Every child shall have, without any discrimination as to race, colour, sex, language, religion, national or social origin, property or birth, the right to such measures of protection as are required by his status as a minor, on the part of his family, society and the State; 2 ) Every child shall be registered immediately after birth and shall have a name; 3 ) Every child has the right to acquire a nationality.

${ }^{25}$ See United Nations Convention on Rights of the Child, Article (7) 1) The child shall be registered immediately after birth and shall have the right from birth to a name, the right to acquire a nationality and. as far as possible, the right to know and be cared for by his or her parents. 2) States Parties shall ensure the implementation of these rights in accordance with their national law and their obligations under the relevant international instruments in this field, in particular where the child would otherwise be stateless.

${ }^{26}$ See The African Charter on the Rights and Welfare of the Child, Article (6) 1) Every child shall have the right from his birth no a name; 2) Every child shall be registered immediately after birth; 3 ) Every child has the right to acquire a nationality.

${ }^{27}$ ibid.
} 
ondary and higher levels, can serve as a protective factor for girls against gender-based violence and has been identified as an important preventive intervention for children at risk of trafficking (United Nations Development Fund for Women. ${ }^{28}$ In addition, governments should ensure that the necessary policies are in place to remove all barriers to girls' participation in education and schooling, such as cultural norms and safety concerns.

\subsection{Raising Public Awareness about Child Trafficking and Child Protection in Nigeria}

The idea of public awareness is central to all debates about child protection in general and child trafficking and its attendant child labour in particular. Awareness raising also known as consciousness raising is a form of activism that is often conducted by a group of people who endeavour to focus the attention of a wider group of people on some cause or condition. Public awareness must been seen as an important element or mean of overcoming child trafficking. Making the communities aware of the negative impacts and consequences of child trafficking on their development and the future of the entire community is paramount. Public awareness involves important stages of educational strategies and empowerment for the communities. Indeed they are given the opportunity to understand facts about child trafficking. More significantly, they are trained to play an active role in combating the phenomenon. In the light of its far reaching effect and its efficacy in practice, public awareness plays a significant role in achieving the ultimate goal of elimination child trafficking or child labour.

Due to the significant role of raising public awareness in combating trafficking in persons in general and child trafficking in particular, government authorities can take the lead in raising awareness not only for the benefit of the population but also for the interest of the country. Thus in the case of child trafficking and child abuses, the authorities have the duty to take the leading role by sending the necessary messages to stakeholders and the general public alike. To some extent the support of the ECOWAS to its member state in fighting child trafficking and child, abuses is necessary. Considering the issues of child trafficking and other child abuses in Nigeria the narrative about their justification or legitimacy should not create any confusion. Whether the issue that imposes the need to raise awareness is motivated by traditional perception or socio-economic perspectives, it remains an adverse practice against the welfare of the child hence a child rights violation issue. Therefore the public should be increasingly aware of the dangers and negative impacts of such practices on children.

In the case of Nigeria, raising awareness must be initiated by the federal government then cascaded at states levels because more consideration will be given to the move by doing so. However raising awareness cannot be considered as a viable alternative to education but it plays an import role in drawing people's attention to critical issues facing the nation. Awareness raising is to be conducted

${ }^{28}$ See UNICEF, "Child protection from violence, exploitation and abuse: Birth Registration". Available at http://www.unicef.org/protection/57929_58010.html, accessed 29 July 2019. 
within every community. This approach does not necessarily require that the group of individuals concerned should be literate or have had a sort of formal education. Although the ideal position would have been that the general public had the necessary level of formal education, the authorities should rely on the realities on the ground. Hence Nigerian authorities should devise strategies that will have a far-reaching effect on the whole population in order to draw their attention to the destructive effect of child trafficking in their communities and the nation. Public awareness is conducted through various means depending on the targeted group of the population. It is conducted through campaigns in rural and urban areas. It is important that the population is aware that the trafficking network has a preference for a specific group in the community.

According to the ILO, traffickers target the most vulnerable group in Nigeria such as women and children from poor rural communities and with little or no education who often constitute the larger percentage of trafficked persons in Nigeria. Traffickers exploit the vulnerability of the people in places where there is general poverty, lack of income generating opportunities and pervading ignorance, to source the victims of trafficking. Indeed the vulnerability of rural dwellers becomes more visible in cases where the children and young people are not only from poor rural communities but are orphans or come from disadvantaged or dysfunctional households. In some cases, human trafficking is facilitated or carried out with the active connivance of members of the victims' families. ${ }^{29}$ Hence raising awareness with those communities could play a significant role because the members of the community will be well equipped to discover subterfuges used by traffickers and their middlemen and also to identify potential traffickers. In the context where child trafficking has become a lucrative trade, it is no more family members only who propose to be guardians or custodians of the child. Other members of the community are now involved in promising better live to the children and their families. Therefore, traffickers use subterfuges to persuade guardians of even parents to give away their children. They often promise to send the child to school with the guarantee of a better life in future. Indeed they promise the best conditions which current guardians or parents themselves cannot create for the upbringing of the child (Meier, 2008). The socio-economic element of the problem has made it more complex than before. Therefore is an imperative for government authorities to raise awareness on the whole issue of child trafficking and child protection.

According to the United Nations Development Programme, capacity building is a long-term, continuing process, in which all stakeholders participate. The stakeholders include government agencies, non-governmental organisations, professional associations, academics and others. The essential element of capacity building in combating child trafficking in Nigeria and the Ecowas regions ${ }^{29}$ See ILO, Review of Legislation and policies in Nigeria on Human Trafficking and Child Labour'. Available at http://www.ilo.org/wcmsp5/groups/public/---ed_norm/---declaration/documents/publication/wcms _083149.pdf, accessed 26 July 2019. 
will focus on human resource development which is the process of equipping individuals all the resources and tools that will make the participate in the development process more effectively. The institutional and legal frameworks development to make legal and regulatory changes is, therefore, necessary. ${ }^{30}$ Building capacity is a form of empowerment to allow all stakeholders to deal with the issue of Trafficking in person with particular attention to child trafficking. They are complex issues that require immediate attention.

\subsection{Building Capacity for Child Protection in Nigeria}

Building capacity will require reforms in many agencies concerned with children and also the elites need training. The paradigm shift in perception can be triggered when there are proper actions towards the training of agents and all those involved in making it happen. The Police trained to deal with the issue of human trafficking in general and child trafficking in particular. The border forces need appropriate training and the resources to carry out a proper border check given that most children are trafficked outside Nigerian borders. Moreover, community leaders and the vast population can have regular workshops. This endeavour could be combined with the campaigns undertaken in the context of awareness raising programmes. Traffickers will use various strategies to thwart efforts made by the authorities to deter them. In a scenario where the authorities do not have the appropriate response to those strategies, it is evident that the criminals will remain unchallenged. Building capacity is to be directed toward every stakeholder in the fight against child trafficking in Nigeria. In the era of new technologies building capacities within border, agencies imply that the agents receive the adequate training to carry out check with equipment adapted to biometric travel documents. An official in the judiciary should get the appropriate training to deal with cases of organised crimes.

The sheer seriousness of the lack of competency and professionalism within Nigerian Police Force has led the authorities to undertake reforms. The reform was part of the President's Transformation Agenda. In the framework of the Agenda, the Ministry of Police Affairs has initiated the transformation of the Nigerian Police Force through the implementation of a six-year Police Reform Programme. The programme lasted from 2010 to 2015. One of the key points on the Reform Agenda was training and capacity building. However this programme has brought some qualitative changes in the Nigerian policing system, there is still some progress to be made to set a force that will play its role. ${ }^{31}$ At least the endeavour towards the human capacity building is a good step towards the modernisation process. Building capacity for all law enforcement agencies is vital to the effective running of the system. The police and the border control officers like are to be well trained and well equipped be efficient in combating child trafficking. The United Nations Office on Drugs and Crimes (UNODC)

${ }^{30}$ Capacity Building-Agenda 21's definition (Chapter 37, UNCED, 1992).

${ }^{31}$ See the Nigerian Ministry of Police Affairs "Police Reform". Available at http://www.policeaffairs.gov.ng/the-police/police-reform, accessed 22 July 2019. 
asserts that criminal intelligence is the lifeblood of the fight against transnational organised crime. ${ }^{32}$ It is crucial to investigations. ${ }^{33}$ Hence Training must be offered to police investigators, prosecutors and judges, criminal intelligence analysts, and organised crime investigators and customs officials. ${ }^{34}$

\section{Revisiting the Legal and Political Approaches to the Phenomenon}

Revisiting the legal and political approaches to the phenomenon of child trafficking in Nigeria aims to show that there is a status quo at various levels of the system put in place to combat child trafficking and guarantee child protection in Nigeria.

\subsection{The State of Affairs about the Legal and Political Approaches in Nigeria}

The lack of accountability in the failure to deliver public administration has worsened the state of affair regarding the protection of human rights in general and child rights in particular. The state of mismanagement of public funds, corruption and dysfunction of the judiciary and law enforcement agencies are issues hindering sustainable development. Since its independence in 1960 Nigeria went through various phases of government. From Civil Governments to military dictatorship for nearly three decades the culture of impunity has been fostered at the top of the state. Unfortunately, the judiciary and the law enforcement agencies alike were embarked on the anti-developmental practices. The lack of accountability in the context of child trafficking seen as a serious child rights violation, both the federal authorities and local authorities appears to have turned a blind eye to a phenomenon that ought to become a matter great concern for them. It is well acknowledged that the law enforcement system is marred by corruption. However, enforcement authorities and government officials alike scarcely hold anybody accountable for the glitch of the system.

For instance, the 2015 United States Department of Sates report places great emphasis on the inefficacy of law enforcement system (OSAC, 2015). Although the report points at the slow or non-response of the Nigerian Police Forces in violent crimes such as arm robbery and kidnapping, the emphasis unveils the key characteristic of ineffective law enforcement system in Nigeria. It should be noted that the report indicates that:

"Law enforcement authorities usually respond slowly or not at all and provide little/no investigative support to victims. A serious lack of resources (communications equipment, vehicles, skilled leadership, training) continues to undermine the effectiveness of the NPF. Usually, victims must maintain close contact to ${ }^{32}$ See UNODC, "Law Enforcement". Available at https://www.unodc.org/unodc/en/organized-crime/law-enforcement.html, accessed 22 July 2019. ${ }^{33}$ ibid.

${ }^{34}$ See UNODC, “Law Enforcement". Available at https://www.unodc.org/unodc/en/organized-crime/law-enforcement.html, accessed 22 July 2019. 
move an investigation forward. Crime laboratories and facilities to process evidence do not exist. As such, most Nigerians do not perceive the NPF as an effective law enforcement body and have little faith in the criminal justice system. A call to police for assistance may result in solicitation of bribes. As a result, criminal groups do not fear arrest or prosecution for their crimes." ${ }^{35}$

Considering the key characteristic as a pattern in general policing in Nigeria, it could be asserted that the predicament exists in the management of criminal activities such as Child trafficking. Indeed child trafficking ranked among the recurring criminal activities in Nigeria. It is argued that a society in which good governance is absent, accountability of governmental agencies and development in such society is likely to be affected negatively (Gberevbie et al., 2014). Kifordu (2010) pertinently observes that the core political executive elite limit political accountability as various changes occur in the political regime and economic sources of government revenue in post-colonial Nigeria. The urgency of the matter led Human Rights Watch to urged Nigerian government officials to endeavour to improve transparency in budgets in the police and to investigate and bring to justice police officers at all levels implicated in corrupts practices. ${ }^{36}$

According to Danjuma, the constant interactions between the rulers and the ruled are central to the achievement of an atmosphere of transparency in governance processes (Danjuma, 2014). Therefore, the argument is transparency and accountability in government enhanced public confidence in the policies of the government. Also, transparency helps to eliminate corruption and mismanagement of public funds meant for development by officials. ${ }^{37}$ Noteworthy, the whole process must be executed in observance of the rule of law. The rule of law in a country constitutes the core element in holding authorities accountable in the excise of their official duties. Hence the idea of the rule of law and legal awareness cannot be dissociated in that the sole existence of the rule of law does not suffice to achieve the purposes for which the rule of law must be manifest; there must also be legal awareness. The rule of law is characterised by the fact the authority of government is exercised legitimately in accordance with written laws and established procedures. The principle is intended to be a safeguard against arbitrary governance. Therefore, the rule of law can be perceived as a concept meaning the predominance of legal standards in the life of civil society. Hence, the lack of the rule of law is lawlessness and social chaos (Neate, 2009).

On the importance of the issue, Weingast (2010) argues that the emergence of the rule of law coincide with the transition from the natural state to the open access order. He rests his postulate upon the idea that natural states have only a limited ability to provide the rule of law, they cannot make either extensive credible commitment to institutions and rules that provided for certainty, ex${ }^{35}$ ibid.

${ }^{36}$ See Human Rights Watch's Report: “Everyone's in on the Game”: Corruption and Human Rights Abuses By the Nigeria Police Force. Available at https://www.hrw.org/report/2010/08/17/everyones-game/corruption-and-human-rights-abuses-nige ria-police-force, accessed 21 July 2019.

${ }^{37}$ ibid. 
pectation or impersonal rules that treat a wide class of citizens equally. ${ }^{38}$ Whereas the state treats citizen impersonally, natural state people personally and hence differently (Weingast, 2010).

Law enforcement could be defined as the implementation of national legislation, usually criminal laws by agencies such as the police. Law and policy enforcement in all legal system come to the final stage of the process in delivering the desire of the authorities to achieve specific goals in the interest of communities and the nation as a whole. Law enforcement, therefore, ought to hit the target aimed at. It is observed that despite the fact that the contribution of legislations in enhancing the legitimacy of a particular decision or project is usually recognised, they face difficulties at the enforcement stage (Juan-Carlos Molleda \& Abubakar, 2006).

More significantly in the context international legal frameworks, authorities should perceive the need for an effective domestication and the subsequent enforcement. Waal and Argenti write that "it is notable that CRC is unique among international conventions in that it not only specifies the obligations of the national government but also lays down international responsibilities for acting in solidarity to promote child rights (De Waal \& Agenti, 2002). These solidarity obligations may be vaguer and less easily enforceable, but they exist". ${ }^{39}$ In the case

of such important legal instruments, Nigerian authorities have an obligation to ensure that not only the laws are implemented but also enforced where necessary because this will demonstrate their commitment to serving the population.

\subsection{Challenges in the Implementation Laws}

International legal instruments including bilateral treaties can certainly be implemented in every country of the world. However, there are contextual challenges especially the lack of adequate structures or infrastructures that can facilitate the success of the implementation and enforcement processes. Paradoxically the authorities seldom look at the necessary conditions for an effective implementation and enforcement. It appears that most governments, especially in the developing countries, tend to domesticate international legal instruments just to comply with their obligations under international law. As a result, the domesticated law is never enforced. The paradox in the implementation of international legal instruments is also evident in a context where developing countries and industrialised country are required to implement the same instruments. Obviously, industrialised countries usually have the necessary resources and infrastructures to domesticate and enforce the law in integrally. Even when e challenges arise in the process, industrialised countries would have the means to overcome them in as swiftly as possible. In adopting a new approach to domestication and implementation of international legal instruments, there is an imperative to assess the condition for an effective implementation and enforcement. Where the situation for ineffective implementation and enforcement be-

${ }^{39}$ ibid. 
come a recurring scenario authorities should endeavour to create the required conditions.

In the case of respecting children's rights across the globe, the United Nations, UNICEF, and various NGOs increasingly support least advantaged countries to fulfil their obligation in term of implementing and enforcing child rights instruments. Hence Nigerian authorities in adopting a new approach to enforcement of laws related to children's rights in general and child trafficking, in particular, should focus on creating the adequate conditions for effective enforcement.

\section{Conclusion}

The discourse on eliminating child trafficking in Nigeria is more or less a discourse on the creation of adequate conditions for an effective child protection. Indeed where the conditions of an effective child protection are in place, and all the protection apparatus ${ }^{40}$ are active, it is almost impossible to encounter the typology and the magnitude of child trafficking and its corollary of abuses currently seen in Nigeria. The observation is significant in that child trafficking regarded as one of the worst practices. Not only the children's rights are violated during the process of trafficking but they also, at the end of the process, find themselves trapped in conditions where their future is put in jeopardy. As analysed in this article, trafficking children may be a short process as it is a way of transporting children from their usual environment to a given destination, but the worst happens to them when various exploitations start. So far the Nigerian authorities have not delivered in term of child protection. From a holistic approach, child protection remains non-existent in Nigeria.

\section{Conflicts of Interest}

The authors declare no conflicts of interest regarding the publication of this paper.

\section{References}

Aderanti, A. (2002). Fostering Free Movement of Persons in West Africa: Achievements, Constraints, and Prospects for Intraregional Migration. International Migration, 40, 3-28. https://doi.org/10.1111/1468-2435.00188

BBC Magazine (2016). The World of Nigeria’s Sex-Trafficking “Air Lords”. BBC News. https://www.bbc.co.uk/news/magazine-35244148

Bradford, A., \& Ben-Shahar, O. (2012). Efficient Enforcement in International Law. Chicago Journal of International Law, 12, 375-431.

Chukwu, L. (2012). Adoption of Children in Nigeria under the Child's Rights Act 2003. Documents.

http://www.law2.byu.edu/isfl/saltlakeconference/papers/isflpdfs/Chukwu.pdf

Danjuma, I. A. (2014). The Role of Transparency and Accountability in the Guest for

${ }^{40}$ The apparatus in this context refers to the relevant laws, policies, structures and mechanism in place to achieve the goals set for the specific purpose. 
Development in Nigeria. African Journal of International Affairs and Development, 17, 49.

De Waal, A., \& Argenti, N. (2002). Young Africa: Realising the Rights of Children and Youth (p. 25). Africa World Press, Inc.

Donnelly, J. (1984). Cultural Relativism and Universal Human Rights. Human Rights Quarterly, 400, 419. https://doi.org/10.2307/762182

Ekpere Johnson, A., Oyedipe, F. P. A., \& Adegboye, R. O. (1978). Family, Role Differentiation within the Kwara Nomadic Fulani. In C. Opong et al. (Eds.), Changing African Family Part 1, Marriage, Fertility and Parenthood in West Africa (pp. 60-61). Canberra: The Australian National University.

Gberevbie, D. et al. (2014). The Challenges of Good Governance, Accountability of Governmental Agencies and Development in Nigeria. Acta Universitatis Danubius: Administration, 6, 80-97.

ILO (2010). Child Trafficking-Essentials. Geneva: International Labour Organization.

Juan-Carlos Molleda, D., \& Abubakar, A. (2006). Professional Views on the Nigeria Institute of Public Relations' Law and Enforcement. Public Relation Review, 32, 68-69. https://doi.org/10.1016/j.pubrev.2005.10.008

Kifordu, H. A. (2010). Political Elite and the Vicissitudes of Accountability in Nigeria. South African Political Studies, 37, 2-3. https://doi.org/10.1080/02589346.2010.522339

Lawrance, B. N. (2010). From Child Labor "Problem" to Human Trafficking "Crisis": Child Advocacy and Anti-Trafficking Legislation in Ghana. International Labor and Working-Class History, 78, 63-88. https://doi.org/10.1017/S0147547910000128

Liepe, B. (2016). Examining the Growth of Witchcraft Accusations in Sub-Saharan Africa. Grand Valley Journal of History, 1, 18.

Magashi, S. B. (2015). Education and the Right to Development of the Child in Northern Nigeria: A Proposal for Reforming the Almajiri Institution. Africa Today, 61, 65-83. https://doi.org/10.2979/africatoday.61.3.65

Marshall, T. H. (1992). Citizenship and Social Class. In T. H. Marshall, \& T. Bottomore (Eds.), Citizenship and Social Class (p. 8). London: Pluto Press.

Matsumoto, D. (2007). Culture, Context, and Behavior. Journal of Personality, 75, 1285, 1320 .

Meier, P. J. (2008). Small Commodities: How Child Traffickers Exploit Children and Families in Intercountry Adoption and What the United States Must Do to Stop Them. The Journal of Gender, Race, and Justice, 12, 185.

Meier, P. J. (2008). Small Commodities: How Child Traffickers Exploit Children and Families in Intercountry Adoption and What the United States Must Do to Stop Them. The Journal of Gender, Race, and Justice, 12, 185.

Neate, F. (2009). The Rule of Law: Perspectives from Around the Globe (p. 43). London: Lexis Nexis.

O'Brien, P. (2006). Historiographical Traditions and Modern Imperatives for the Restoration of Global History. Journal of Global History, 1, 3-39. https://doi.org/10.1017/S1740022806000027

Oni, B. J. (1995). Fostered Children's Perception of Their Health Care and Illness Treatment in Ekiti Yoruba Households, Nigeria. Health Transition Review, 5, 21-34.

OSAC (2015). Nigeria 2015 Crime and Safety Report. Lagos. https://www.osac.gov/Content/Browse/Report

Oyowe, O. A. (2014). An African Conception of Human Rights? Comments on the Chal- 
lenges of Relativism. Human Rights Review, 15, 329-347.

https://doi.org/10.1007/s12142-013-0302-2

Oyserman, D. (2011). Culture as Situated Cognition: Cultural Mindsets, Cultural Fluency and Meaning Making. European Review of Social Psychology, 22, 164-214. https://doi.org/10.1080/10463283.2011.627187

Pope, W. (1975). Durkheim as a Functionalist. The Sociological Quarterly, 16, 361-379. https://doi.org/10.1111/j.1533-8525.1975.tb00954.x

Roose, R., \& Bouverne-De Bie, M. (2007). Do Children Have Rights or Do Their Rights Have to Be Realised? The United Nations Convention on the Rights of the Child as a Frame of Reference for Pedagogical Action. Journal of Philosophy of Education, 41, 431-443. https://doi.org/10.1111/j.1467-9752.2007.00568.x

Secker, E. (2013). Witchcraft Stigmatization in Nigeria: Challenges and Successes in the Implementation of Child Rights. International Social Work, 56, 22-36. https://doi.org/10.1177/0020872812459065

Thompson, E. P. (1966). The Making of the English Working Class (p. 307). New York: Vintage Books.

United Nations (2015). The Millennium Development Goals Report 2015. Documents. http://www.un.org/millenniumgoals/2015_MDG_Report/pdf/MDG\%202015\%20rev\%2 0(July\%201).pdf

US Department of States (2015). 2015 Trafficking in Person Report: Nigeria. http://www.state.gov/j/tip/rls/tiprpt/countries/2015/243505.htm

Weingast, B. R. (2010). Why Developing Countries Prove So Resistant to the Rule of Law. In J. J. Heckman et al. (Eds.), Global Perspectives on the Rule of Law (p. 40). London: Routledge.

Williamson, J. G. (1991). Child Labor and Industrial Revolution. Population and Development Review, 17, 534, 536.

Withnall, A. (2016). Aid Worker Who Rescued a Boy from Starvation Reveals How She Is Working to Save Nigeria's "Witch Children". Independent.

https://www.independent.co.uk/news/world/africa/aid-worker-who-rescued-a-boy-fro m-starvation-reveals-how-she-is-working-to-save-nigerias-witch-a6881101.html

Zwari, T. (2012). Using Local Culture to Further the Implementation of International Human Rights: The Receptor Approach. Human Rights Quarterly, 34, 546-569. https://doi.org/10.1353/hrq.2012.0020 